\title{
Simulation of Wheat Growth and Yield under Ambiance Change Impacts on Crop in Eastern India
}

\author{
Shatruhan Jaiswal*, Anuj Kumar and Uma Shanker Gupta \\ Agriculture Engineering, Faculty of Agriculture, Abhilashi University Chailchowk Chachiyot, \\ Distt-Mandi- (H.P), 175028, India \\ *Corresponding author
}

\begin{abstract}
A B S T R A C T
In India, wheat is grown in an area of about 29.06 million hectares with a production of 86.87 million ton (FAO, 2011). The yield of wheat increased after sixties and early seventies bringing the green revolution in India. In recent years, production of wheat crop

\section{Keywords}

Wheat, Wheather, $\mathrm{CO}_{2}$, CERES model and simulation

Article Info

Accepted:

26 June 2018

Available Online:

10 July 2018 in response to the increasing application rates of the input resources is experiencing a declining trend. India is second most populous country after China which houses $15 \%$ of global population (census 2011) within $2.42 \%$ of geographical land area of world. The ever growing population and improving economic condition pressurize to produce and supply higher quantity of food grains. However, the country's agriculture production is not increasing but somewhere stagnated, this increasing demand for food grain production. Agriculture sector therefore needs much attention to decrease this gap between increasing demand and production. It concluded that the wheat sowing period around 30 November was simulated to be the best for increased production under the current and future climate scenario at Kharagpur, eastern India, A marginal increase in yield was simulated by shifting the sowing time from 30 Nov to 15 December under future climate scenarios. and The $\mathrm{N}$ fertilizer application rate in the range 120 to $180 \mathrm{~kg} / \mathrm{ha}$ was recommended for the yield maximization.
\end{abstract}

\section{Introduction}

The ever growing population and improving economic condition pressurize to produce and supply higher quantity of food grains. However, the country's agriculture production is not increasing but somewhere stagnated, this increasing demand for food grain production. Agriculture sector therefore needs much attention to decrease this gap between increasing demand and production. Wheat, the staple cereal crop in world, is grown in 220.38 million hectare contributing $27.21 \%$ of total cereal grain production. In India, wheat is grown in an area of about 29.06 million hectares with a production of 86.87 million ton (FAO, 2011). The yield of wheat increased after sixties and early seventies bringing the green revolution in India. In recent years, production of wheat crop in response to the increasing application rates of the input resources is experiencing a declining trend. Srivastava et al., (2010) studied the impacts of climate change on the sorghum production system in India using InfoCrop-SORGHUM simulation model. Climate change impacts on 
winter crop are projected to reduce yields up to $7 \%$ by 2020 , up to $11 \%$ by 2050 and up to $32 \%$ by 2080 . The study indicated that more low-cost adaptation strategies should be explored to further reduce the net vulnerability of sorghum production system in India. Xiao et al., (2010) evaluate the effects of temperature on winter wheat (Triticum aestivum L.) at the Tongwei County, Gansu, in the semiarid northwest of China from 2006 to 2008. Crop yields at both high and low altitudes will likely increase, although this increase in yields will be greater at higher elevations. Indeed, it is expected that by 2050 the increased temperature will have induced $2.6 \%$ increase in wheat yields at low altitudes and $6.0 \%$ increase in yields at high altitudes in the study area. The results of this study indicated that $0.6-2.2{ }^{\circ} \mathrm{C}$ increase in temperature will improve the water use efficiency of winter wheat plants at the two altitudes evaluated here.

Langensiepen et al., (2008) validated the CERES-Wheat model under North German environmental condition using nine years of field observation data. They observation that magnitudes of most genetic coefficients were affected by seasonal weather fluctuation. Their modeling results showed a RMSE of $2.2 \mathrm{t} / \mathrm{ha}$ and $3.2 \mathrm{t} / \mathrm{ha}$ for predicted yield and biomass respectively. Dettori et al., (2011) used the CERES-Wheat model to test the predictive performance of model, implemented in DSSAT software system, under Mediterranean climate condition and soil types of Southern Sardinia, Italy. CERES-Wheat model was calibrated for three durum wheat Italian varieties (Creso, Duilio, and Simeto) using a 30 years data set (1974-2004). The results of their study, based on long-term data sets, supported their conclusion that further model testing and testing and improvements are required for application on durum wheat and the need of proper calibration and validation in the environment of interest.
Singh et al., (2008) used the CERES-Wheat and CropSyst models for predicting growth and yield of wheat under different nitrogen and water management conditions. The models were evaluated for three irrigation and five nitrogen treatments. Both the models were calibrated using data obtained from the treatments receiving maximum nitrogen and irrigations, i.e., $\mathrm{N} 150$ and 14 treatments. It was observed that the model predicted grain yield satisfactorily with R2 $=0.88$ but under estimated the biomass. Nagarajan et al., (2010) studied the impact of diurnal temperature and radiation changes on yield and yield components of aromatic rice cultivars in field conditions and documented the effect of changing diurnal temperature and radiation on grain quality. The results showed that the optimum planting dates have been established in most of the rice-growing regions of the world and the option to alter them according to changing climate could result in a yield penalty and altered grain quality. Mutlu Ozdoğan (2011) investigated the impacts of elevated atmospheric $\mathrm{CO} 2$ concentrations and associated changes in climate on winter wheat yields in northwestern Turkey. They suggested prioritization of adaptation strategies in the region, including development of local cultivars of drought and heat-resistant crop varieties, earlier planting to avoid heat stress during summer, development and adoption of slower-maturing varieties to increase the grain filling period, and further investments to boost agricultural productivity with the objective of Simulation of wheat yield under climate change scenarios and Evaluation of agro-adaptation for wheat production under climate change scenario.

\section{Materials and Methods}

\section{Growth and yield simulation}

Crop growth is simulated by employing a carbon balance approach in a source-sink 
system (Ritchie et al., 1998). Daily crop growth rate is calculated as:

PCARB $=\frac{\text { RUE } \times \text { PAR }}{\text { PLTPOP }}\left(1-\mathrm{e}^{(-\mathrm{k} \times \text { LAI })}\right) \times \mathrm{CO}_{2}$

Where,

PCARB $=$ Potential growth rate, $\mathrm{g} /$ plant

RUE = Radiation use efficiency, (gm dry matter/MJ PAR)

PAR $=$ Photosynthetically active radiation $\left(\mathrm{MJ} / \mathrm{m}^{2}\right)$

PLTPOP $=$ Plant population, plants $/ \mathrm{m}^{2}$

$\mathrm{K}=$ Light extinction factor

$\mathrm{LAI}=$ Green leaf area index

$\mathrm{CO}_{2}=$ Carbon dioxide concentration (ppm)

The stages of development are determined by the accumulation of thermal time (Growing degree days).

Thermal time is computed with the following equation:

$$
\begin{aligned}
& \mathrm{GD}_{\text {day }}=\mathrm{T}_{\text {avg }}-\mathrm{T}_{\text {GDdaysbase }} \\
& \mathrm{CGD}_{\text {day }}=\mathrm{CGD}_{\text {day }-1}+\mathrm{GD}_{\text {day }} \\
& \mathrm{T}_{\text {avg }}= \begin{cases}\mathrm{T}_{\text {GDdaybase }} & \text { if } \mathrm{T}_{\text {avg }}<\mathrm{T}_{\text {GDdaybase }} \\
\mathrm{T}_{\text {cutoff }} & \text { if } \mathrm{T}_{\text {avg }}>\mathrm{T}_{\text {cutoff }} \\
\left(\mathrm{T}_{\max }+\mathrm{T}_{\min }\right) / 2 & \text { 0therwise }\end{cases}
\end{aligned}
$$

Where,

GDday $\left({ }^{\circ} \mathrm{C}\right.$-days) is today's thermal time.

CGDday $\left({ }^{\circ} \mathrm{C}\right.$-days) is today's accumulated thermal time since planting.

TGDdaybase and Tcutoff are crop input parameters that define the range of temperatures for viable development.

Tmin $\left({ }^{\circ} \mathrm{C}\right)$ is the daily minimum air temperature.

Tmax $\left({ }^{\circ} \mathrm{C}\right)$ is the daily maximum air temperature.

\section{Simulation of climate change impact}

Wheat phenological development, biomass and grain yield where simulated for different climate change scenarios and also for past weather. Fixed climate change scenarios of rising $\mathrm{CO}_{2}$ level and temperature above the current value and developed scenarios of HadCM3 for the year 2020 and 2050 generated from Global Climate Model were used for the simulation analysis. The fixed scenarios include the combination four levels elevated $\mathrm{CO}_{2}(+0,+100,+200$ and $+300 \mathrm{ppm})$ and four level of rising temperature $(+0,+1$, +2 , and $\left.+3{ }^{\circ} \mathrm{C}\right)$ above the ambient $\mathrm{CO}_{2}\left(\mathrm{CO}_{2}\right.$ $\simeq 390 \mathrm{ppm}$ ). Future weather data of the study areas for the years 2020s and 2050s based on downscaling GCM (Global Climate Model) of HadCM3 were collected from Space Applications Center (SAC), Ahmedabad for the two climate scenarios 'A2' and 'B2' where A2 considers industrial development and B2 considers environmental sustainability on regional level. The future climate scenarios were used in the CERES model to simulate their effect on growth and yield of wheat crop.

\section{Evaluation of agro-adaptation}

Evaluation of adaptive management options is very crucial for successfully dealing with climate change impacts. The CERES-wheat model was used for simulation of different adaptation management. This adaptation management includes effect of change in planting date and in nitrogen application rate for minimizing the adverse impact of climate change in wheat yield. 


\section{Study site}

The present study has been carried out in the research farm of Agricultural and Food Engineering Department, Indian Institute of Technology Kharagpur, Kharagpur $\left(22^{\circ} 19^{\prime} \mathrm{N}\right.$ latitude and $87^{\circ} 19^{\prime} \mathrm{E}$ longitude) India. The climate of Kharagpur is classified as sub humid, sub tropical with hot and humid in summer (April and May), rainy during June to September, moderately hot and dry in autumn (October and November), cool and dry in winter (December and January) and moderate spring in February and March. The daily mean temperature of the study area ranges from a minimum of $12{ }^{\circ} \mathrm{C}$ in January to a maximum of $37{ }^{\circ} \mathrm{C}$ in April with average annual rainfall of $1400 \mathrm{~mm}$. The variation in average daily maximum and minimum temperatures, solar radiation and rainfall for the study area during $1971-2012$

\section{CERES-Wheat model}

The CERES-Wheat model simulates phenological development of the crop; growth of grains, leaves, stems, and roots; biomass accumulation based on light interception and environmental stresses; soil water balance; and soil $\mathrm{N}$ transformations and uptake by the crop. The phenology component also simulates the effect of water or $\mathrm{N}$ deficit on the rate of life cycle progress (Singh et al., 1999). The duration of growth stages in response to temperature and photoperiod varies between species and cultivars, and genetic coefficients are used as model inputs to describe these differences. The phenological stages simulated by the model are sowing, germination, emergence, juvenile phase, panicle initiation, heading, beginning of grain filling, end of grain filling, and physiological maturity. The model simulates total biomass of the crop as the product of the growth duration and average growth rate. The simulation of yields at the process level involves the prediction of these two important processes. The yield of the crop is the fraction of total biomass partitioned to grain.

\section{Input parameters}

Input requirements for CERES-Wheat include site characteristics weather and soil conditions, plant characteristics, and crop management (Hunt et al., 2001).

\section{Site}

Latitude, longitude, elevation, slope, water table depth.

\section{Weather}

Daily solar radiation, maximum and minimum air temperature, and precipitation. Solar radiation can be approximated from other observations, such as the number of sunshine hours, which is sometimes more readily available.

\section{Soil}

Physical properties: Depths of layers, percentages of sand, silt, and clay, and bulk density at various depths, moisture content at lower limit (LL, 15 bars), drained upper limit (DUL, 1/3 bar), and at saturation (SAT) for various depths (if they are not available, they could be estimated from percentages of sand, silt, and clay and bulk density).

Chemical properties: $\mathrm{pH}$, organic carbon, total nitrogen, Cation Exchange Capacity.

Crop management: Plant population, planting depth, and date of planting, irrigation and fertilizer scheduling, tillage operations and residue management etc.

Genetic coefficients: Coefficients related to photoperiod sensitivity, duration of grain filling, conversion of mass to grain number, 
grain filling rates, vernalization requirements, stem size, and cold hardiness.

\section{Results and Discussion}

\section{Simulation of climate change impacts}

\section{Past weather}

The model was applied to simulate the grain yield of wheat crop, using the historical weather data (Figure 1). The simulated grain yield over past years is decreasing trend with progress of year. The influence of different sowing dates (15 October, 30 October, 15 November, 30 November, 15 December, 30 December and 15 January) and $\mathrm{N}$ fertilizer doses $(0,60,120,180$ and $240 \mathrm{~kg} / \mathrm{ha})$ was simulated on yield of wheat crop (Table 1). The minimum grain yield of $2729 \mathrm{~kg} / \mathrm{ha}$ was simulated on 15 October sowing and maximum grain yield of $3737 \mathrm{~kg} / \mathrm{ha}$ on 30 November sowing. Among the different sowing dates, sowing on 30 November was taken as reference date since maximum yield was simulated on this date. Percentage change in the yield for the dates earlier to 30 November i.e. 15 November, 30 October and 15 November were $-6,-20$ and -27 , respectively.

Similarly the percentage change in simulated grain yield for the sowing later to 30 November i.e. 15 December, 30 December and 15 January were $-1,-5$ and -21 , respectively, as shown in Figure 2. Increase N fertilizer level up to 120 and $180 \mathrm{~kg} / \mathrm{ha}$ simulated on yield improvement 30 and $36 \%$ as compared to control (no $\mathrm{N}$ application rate). Further $\mathrm{N}$ application did not simulated any significant yield improvement.

The tops weight and water use efficiency were found maximum sowing on 30 November (Table 2 and Table 3). Appearance of anthesis and maturity were 66 and 103 days after sowing for 30 November sowing date. Sowing earlier or later to 30 November reduced the maturity duration 8 and 17 days (Fig. 3).

\section{Global climate model scenario}

The $\mathrm{CO}_{2}$ concentration for the current periods, 2020 and 2050 were 390 ppm, 420 ppm and $480 \mathrm{ppm}$, respectively in A2 as well as B2 scenarios. The change in daily average temperature and monthly rainfall for A2 and B2 scenarios for the periods 2020 and 2050 are shown in Figures 4 to 6 . The average rise in daily air temperature was $0.96{ }^{\circ} \mathrm{C}$ and 2.50 ${ }^{\circ} \mathrm{C}$ for 2020 and 2050, respectively under A2 scenario. Similarly in B2 scenario, the rise on temperature was $1.06{ }^{\circ} \mathrm{C}$ and $2.04{ }^{\circ} \mathrm{C}$ for 2020 and 2050 , respectively.

The change in monthly rainfall factor was 0.21 and 0.23, 2020 and 2050, respectively for A2 scenario, and for B2 scenario the corresponding the changes were 0.22 and 0.26 .

The CERES-Wheat model was used for simulation of grain yield, tops weight, water use efficiency, anthesis and maturity days of wheat for the future climate scenarios. The simulated grain yield, tops weight and water use efficiency are given in Table 6. The percentage change in grain yield for $\mathrm{A} 2$ and B2 scenario was calculated on the basis of current grain yield. The simulated grain yield increased by $12 \%$ and $8 \%$ on 2020, but decreased by $4 \%$ and $3 \%$ in 2050 under A2 and B2 scenario, respectively as compared to present grain yield (Figure 7).

The change in anthesis and maturity days is shown in Figure 8. The water use efficiency was found to be decreasing from A2 2020 to A2 2050 and similar trend was obtained for B2 scenarios. The crop maturity duration was reduced by 2 days in 2020 and 10 days in 2050 (Table 1-10 and Fig. 9-14). 
Table.1 Effect of different sowing dates and nitrogen fertilizer application rate on wheat grain yield $(\mathrm{kg} / \mathrm{ha})$

\begin{tabular}{|c|c|c|c|c|c|c|}
\hline \multirow{2}{*}{$\begin{array}{c}\text { Sowing } \\
\text { dates }\end{array}$} & \multicolumn{5}{|c|}{ N fertilizer (kg/ha) } & \multirow{2}{*}{ Mean } \\
\cline { 1 - 6 } 15-Oct & 2189 & 256 & 120 & 180 & 240 & \\
\hline 30-Oct & 2486 & 2883 & 3099 & 3236 & 3329 & 2729 \\
\hline 15-Nov & 2849 & 3373 & 3649 & 3787 & 3863 & 3504 \\
\hline 30-Nov & 3036 & 3588 & 3886 & 4042 & 4132 & 3737 \\
\hline 15-Dec & 2996 & 3575 & 3873 & 4028 & 4117 & 3718 \\
\hline 30-Dec & 2791 & 3391 & 3717 & 3893 & 3989 & 3556 \\
\hline 15-Jan & 2223 & 2803 & 3128 & 3284 & 3369 & 2962 \\
\hline Mean & 2653 & 3168 & 3455 & 3608 & 3696 & \\
\hline
\end{tabular}

Table.2 Effect of different sowing dates of nitrogen fertilizer application rate on wheat tops weight $(\mathrm{kg} / \mathrm{ha})$

\begin{tabular}{|c|c|c|c|c|c|c|}
\hline \multirow{2}{*}{$\begin{array}{c}\text { Sowing } \\
\text { dates }\end{array}$} & \multicolumn{5}{|c|}{$\mathbf{N}$ fertilizer levels $(\mathbf{k g} / \mathbf{h a})$} & Mean \\
\hline 15-Oct & 0 & 60 & 120 & 180 & 240 & \\
\hline 30-Oct & 7098 & 7902 & 8585 & 8963 & 9159 & 8249 \\
\hline 15-Nov & 7405 & 9743 & 10638 & 10940 & 11083 & 9962 \\
\hline 30-Nov & 7514 & 9862 & 10863 & 11251 & 11422 & 10182 \\
\hline 15-Dec & 7452 & 9489 & 10381 & 10723 & 10888 & 9787 \\
\hline 30-Dec & 6512 & 8319 & 9123 & 9486 & 9668 & 8622 \\
\hline 15-Jan & 5325 & 6761 & 7468 & 7779 & 7936 & 7054 \\
\hline Mean & 6849 & 8707 & 9501 & 9843 & 10016 & \\
\hline
\end{tabular}

Table.3 Effect of different sowing dates and nitrogen fertilizer application rate on wheat water use efficiency $(\mathrm{kg} / \mathrm{ha}-\mathrm{cm})$ of wheat crop

\begin{tabular}{|c|c|c|c|c|c|c|}
\hline \multirow{2}{*}{$\begin{array}{c}\text { Sowing } \\
\text { dates }\end{array}$} & \multicolumn{5}{|c|}{ N fertilizer levels (kg/ha) } & \multirow[t]{2}{*}{ Mean } \\
\hline & 0 & 60 & 120 & 180 & 240 & \\
\hline 15-Oct & 92 & 105 & 113 & 118 & 121 & 110 \\
\hline 30-Oct & 95 & 107 & 114 & 118 & 121 & 111 \\
\hline 15-Nov & 103 & 116 & 123 & 127 & 130 & 120 \\
\hline 30-Nov & 102 & 117 & 124 & 128 & 132 & 121 \\
\hline 15-Dec & 95 & 109 & 116 & 120 & 123 & 113 \\
\hline 30-Dec & 87 & 101 & 109 & 114 & 116 & 105 \\
\hline 15-Jan & 68 & 83 & 91 & 95 & 97 & 86 \\
\hline Mean & 92 & 105 & 113 & 117 & 120 & \\
\hline
\end{tabular}


Table.5 Effect of different sowing dates and nitrogen fertilizer application rate on grain yield ( $\mathrm{kg} / \mathrm{ha}$ ) under $\mathrm{CO}_{2}$ elevation of $+200 \mathrm{ppm}$ and rise in temperature $+2{ }^{\circ} \mathrm{C}$ above current value

\begin{tabular}{|c|c|c|c|c|c|c|}
\hline \multirow{2}{*}{$\begin{array}{c}\text { Sowing } \\
\text { dates }\end{array}$} & \multicolumn{5}{|c|}{ N Fertilizer (kg/ha) } & \multirow{2}{*}{ Mean } \\
\cline { 1 - 6 } 15-Oct & 2171 & 2547 & 2812 & 2966 & 3048 & 2709 \\
\hline 30-Oct & 2384 & 2784 & 3010 & 3149 & 3243 & 2914 \\
\hline 15-Nov & 2608 & 3111 & 3394 & 3533 & 3612 & 3252 \\
\hline 30-Nov & 2785 & 3303 & 3617 & 3776 & 3866 & 3469 \\
\hline 15-Dec & 2751 & 3297 & 3604 & 3760 & 3852 & 3453 \\
\hline 30-Dec & 2458 & 2989 & 3299 & 3471 & 3559 & 3155 \\
\hline 15-Jan & 1931 & 2416 & 2672 & 2787 & 2850 & 2531 \\
\hline Mean & 2441 & 2921 & 3201 & 3349 & 3433 & \\
\hline
\end{tabular}

Table.6 Effect of different sowing dates and nitrogen fertilizer application water use efficiency $(\mathrm{kg} / \mathrm{ha}-\mathrm{cm})$ under $\mathrm{CO}_{2}$ elevation of $+200 \mathrm{ppm}$ and rise in temperature $+2{ }^{\circ} \mathrm{C}$ above current value

\begin{tabular}{|c|c|c|c|c|c|c|}
\hline \multirow{2}{*}{$\begin{array}{c}\text { Sowing } \\
\text { dates }\end{array}$} & \multicolumn{5}{|c|}{ N Fertilizer (kg/ha) } & \multirow{2}{*}{ Mean } \\
\hline 15-Oct & 96 & 60 & 120 & 180 & 240 & \\
\hline 30-Oct & 96 & 109 & 118 & 123 & 126 & 114 \\
\hline 15-Nov & 98 & 112 & 116 & 121 & 124 & 113 \\
\hline 30-Nov & 100 & 114 & 122 & 125 & 127 & 116 \\
\hline 15-Dec & 94 & 108 & 117 & 127 & 129 & 118 \\
\hline 30-Dec & 80 & 94 & 103 & 107 & 123 & 113 \\
\hline 15-Jan & 60 & 73 & 79 & 82 & 84 & 99 \\
\hline Mean & 89 & 103 & 111 & 115 & 117 & 76 \\
\hline
\end{tabular}

Table.10 Simulated wheat grain yield (kg/ha) for the year 2050 under A2 climate scenarios of HadCM3 for different sowing dates

\begin{tabular}{|c|c|c|c|c|c|c|}
\hline \multirow{2}{*}{$\begin{array}{c}\text { Sowing } \\
\text { date }\end{array}$} & 0 & 60 & 120 & 180 & 240 & \multirow{2}{*}{ Mean } \\
\hline 15-Oct & 1346 & 1502 & 1604 & 1649 & 1666 & 1553 \\
\hline 30-Oct & 2072 & 2422 & 2600 & 2714 & 2789 & 2519 \\
\hline 15-Nov & 2809 & 3276 & 3482 & 3599 & 3676 & 3368 \\
\hline 30-Nov & 3106 & 3595 & 3796 & 3909 & 3980 & 3677 \\
\hline 15-Dec & 3161 & 3623 & 3809 & 3920 & 3988 & 3700 \\
\hline 30-Dec & 2870 & 3330 & 3533 & 3659 & 3739 & 3426 \\
\hline 15-Jan & 2226 & 2641 & 2861 & 2989 & 3068 & 2757 \\
\hline Mean & 2513 & 2913 & 3098 & 3206 & 3272 & \\
\hline
\end{tabular}


Table.7 Simulated water use efficiency $\mathrm{kg} / \mathrm{ha}-\mathrm{cm}$ ) for the year 2050 under A2 climate scenarios of HadCM3 for different sowing dates

\begin{tabular}{|c|c|c|c|c|c|c|}
\hline \multirow{2}{*}{$\begin{array}{c}\text { Sowing } \\
\text { dates }\end{array}$} & \multicolumn{5}{|c|}{ N Fertilizer (kg/ha) } & \multirow{2}{*}{ Mean } \\
\cline { 1 - 6 } 15-Oct & 0 & 60 & 120 & 180 & 240 & \\
\hline 30-Oct & 84 & 69 & 72 & 73 & 73 & 70 \\
\hline 15-Nov & 93 & 104 & 108 & 111 & 113 & 106 \\
\hline 30-Nov & 95 & 106 & 111 & 113 & 114 & 108 \\
\hline 15-Dec & 93 & 102 & 106 & 109 & 110 & 104 \\
\hline 30-Dec & 81 & 91 & 95 & 98 & 99 & 93 \\
\hline 15-Jan & 64 & 73 & 78 & 80 & 82 & 75 \\
\hline Mean & 82 & 91 & 95 & 97 & 99 & \\
\hline
\end{tabular}

Table.8 Simulated wheat grain yield (kg/ha) for the year 2050 under B2 climate scenarios of HadCM3 for different sowing dates

\begin{tabular}{|c|c|c|c|c|c|c|}
\hline \multirow{2}{*}{$\begin{array}{c}\text { Sowing } \\
\text { dates }\end{array}$} & \multicolumn{5}{|c|}{ N Fertilizer (kg/ha) } & \multirow{2}{*}{ Mean } \\
\cline { 2 - 6 } 15-Oct & 1575 & 1774 & 1904 & 1970 & 1997 & 1844 \\
\hline 30-Oct & 2297 & 2680 & 2876 & 2997 & 3076 & 2785 \\
\hline 15-Nov & 3026 & 3521 & 3743 & 3851 & 3919 & 3612 \\
\hline 30-Nov & 3253 & 3752 & 3950 & 4071 & 4138 & 3833 \\
\hline 15-Dec & 3219 & 3719 & 3905 & 4022 & 4088 & 3791 \\
\hline 30-Dec & 2884 & 3336 & 3538 & 3661 & 3748 & 3433 \\
\hline 15-Jan & 2276 & 2654 & 2867 & 2995 & 3065 & 2771 \\
\hline Mean & 2647 & 3062 & 3255 & 3367 & 3433 & \\
\hline
\end{tabular}

Table.9 Simulated water use efficiency $(\mathrm{kg} / \mathrm{ha}-\mathrm{cm})$ for the year 2050 under B2 climate scenarios of HadCM3 for different sowing dates

\begin{tabular}{|c|c|c|c|c|c|c|}
\hline \multirow{2}{*}{$\begin{array}{c}\text { Sowing } \\
\text { dates }\end{array}$} & 0 & 60 & 120 & 180 & 240 & \multirow{2}{*}{ Mean } \\
\hline 15-Oct & 72 & 78 & 81 & 83 & 84 & 80 \\
\hline 30-Oct & 87 & 97 & 102 & 105 & 106 & 99 \\
\hline 15-Nov & 99 & 110 & 115 & 118 & 120 & 113 \\
\hline 30-Nov & 99 & 110 & 115 & 117 & 118 & 112 \\
\hline 15-Dec & 94 & 104 & 108 & 110 & 112 & 106 \\
\hline 30-Dec & 82 & 91 & 95 & 98 & 100 & 93 \\
\hline 15-Jan & 66 & 74 & 79 & 82 & 83 & 77 \\
\hline Mean & 86 & 95 & 99 & 102 & 103 & \\
\hline
\end{tabular}


Table.4 Simulated wheat grain yield, tops weight and water use efficiency for the year 2020 and 2050 under A2 and B2 climate scenario of HadCM3

\begin{tabular}{|l|c|c|c|c|}
\hline & \multicolumn{2}{|c|}{ A2 } & \multicolumn{2}{c|}{ B2 } \\
\hline & 2020 & 2050 & 2020 & 2050 \\
\hline Grain yield (kg/ha) & 4355 & 3746 & 4345 & 3905 \\
\hline Tops weight (kg/ha) & 11866 & 10344 & 11711 & 10583 \\
\hline $\begin{array}{l}\text { Water use Efficiency } \\
\text { (kg/ha-cm) }\end{array}$ & 145 & 133 & 145 & 137 \\
\hline
\end{tabular}

Figure.1a Simulated grain yields in past years (1975-2011) for wheat crop

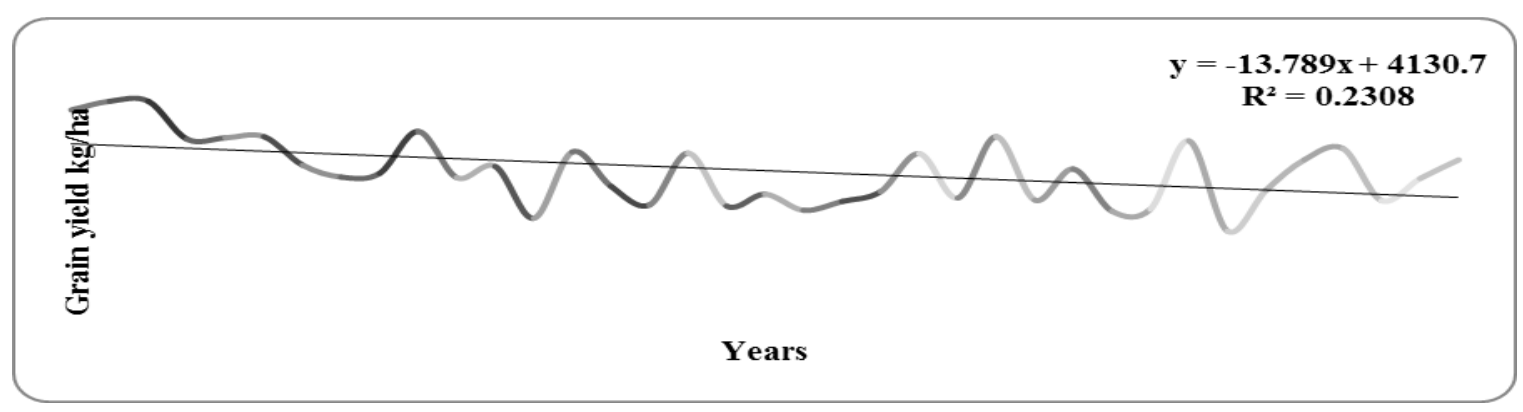

Figure.1b Average daily temperature of past years at Medinipur during 1975-2012

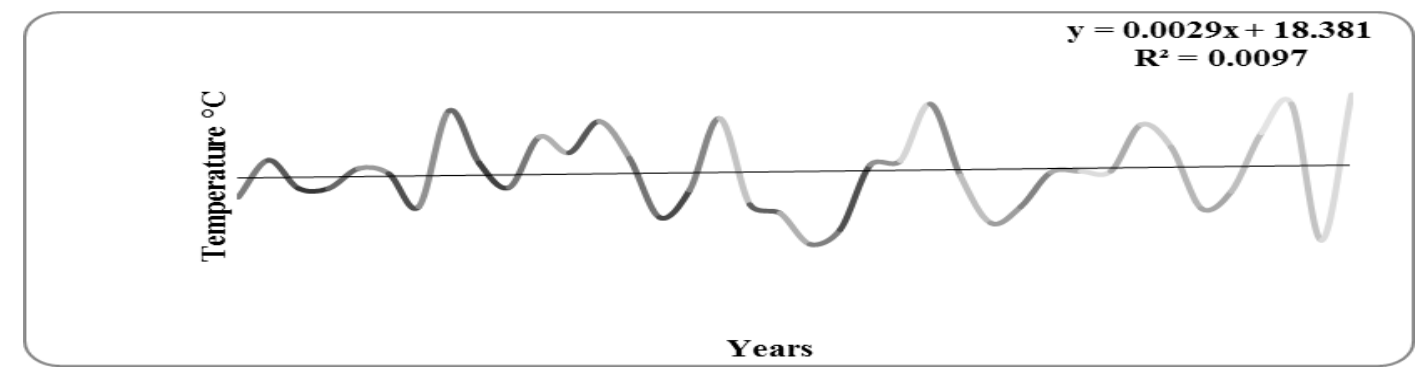

Figure.2 Change in wheat grain yield (\%) under different sowing dates and $\mathrm{N}$ fertilizer application rate as compared to the reference sowing date (30 November) and $\mathrm{N}$ fertilizer rate $(120 \mathrm{~kg} / \mathrm{ha})$

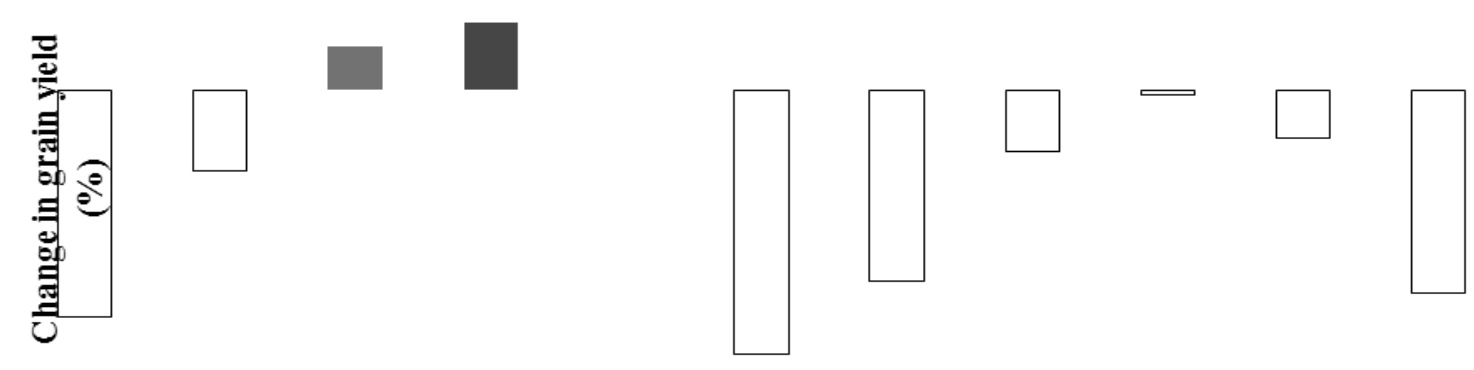


Figure.3 Effect of different sowing date on appearance of anthesis and maturity in days after sowing of wheat crop

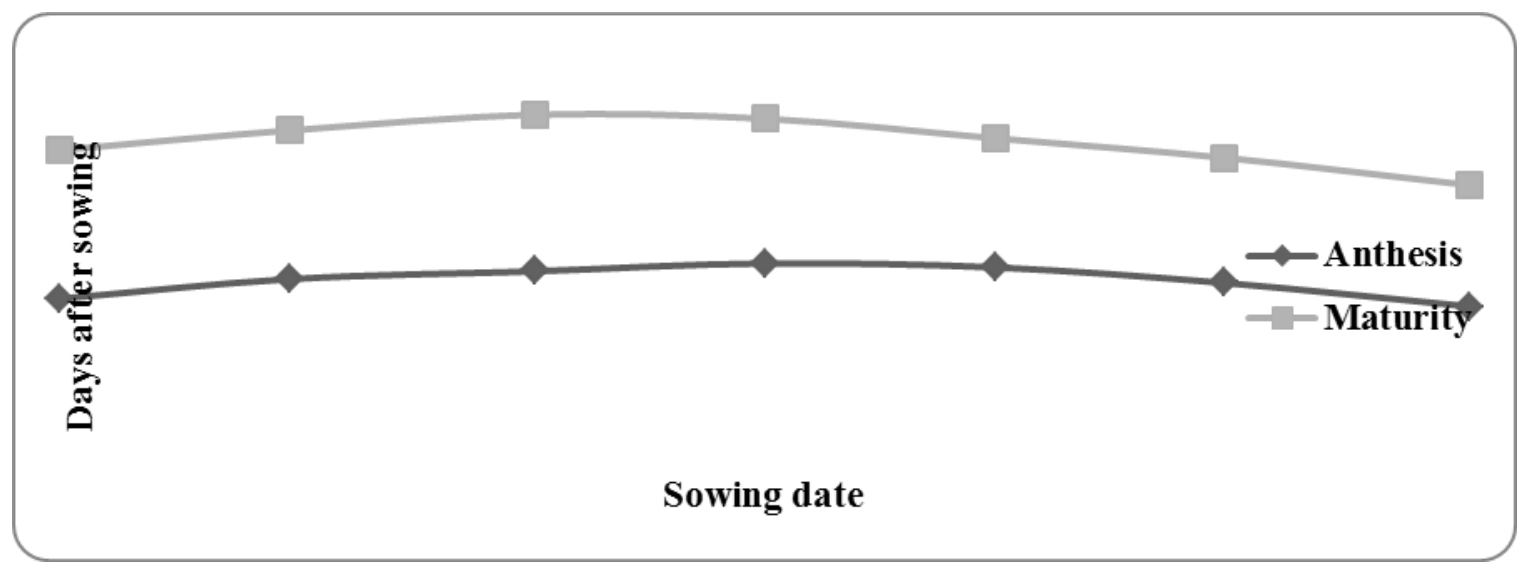

Figure.4 Change in daily maximum temperature for the years 2020 and 2050 in A2 and B2 scenarios of HadCM3

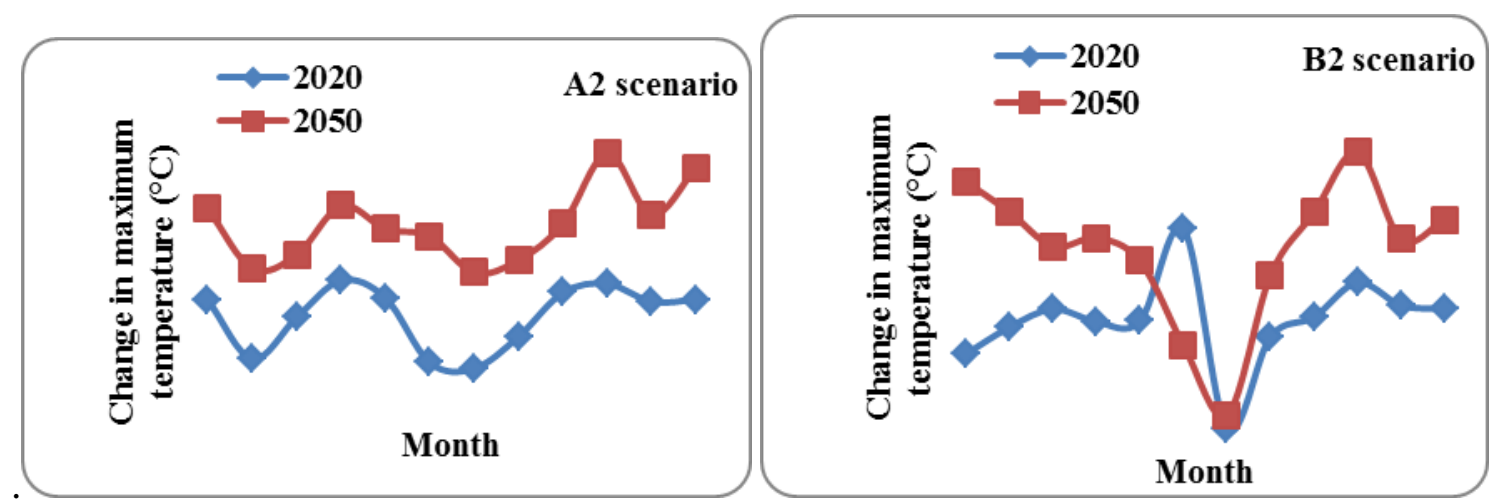

Figure.5 Change in daily minimum temperature for the years 2020 and 2050 in A2 and B2 scenarios of HadCM3

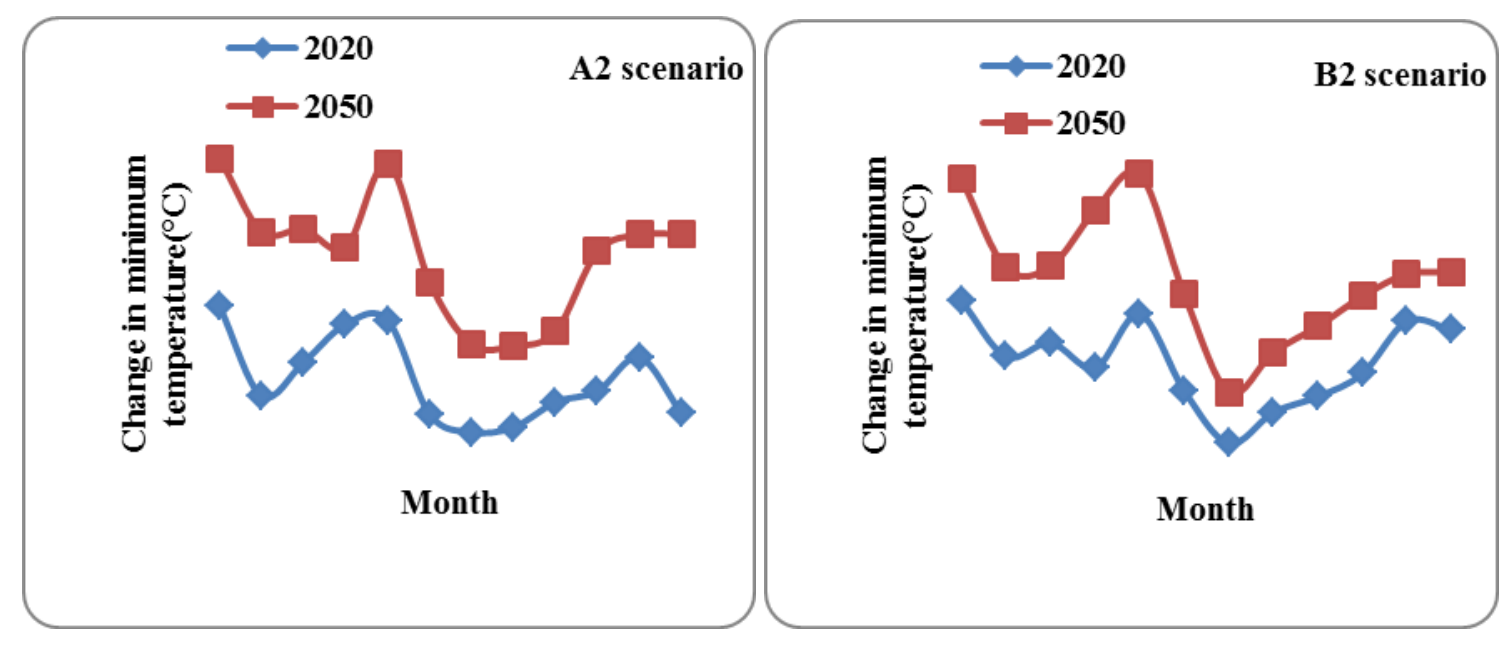


Figure.6 Change in monthly rainfall factor for the years 2020 and 2050 in A2 and B2 scenarios of $\mathrm{HadCM} 3$

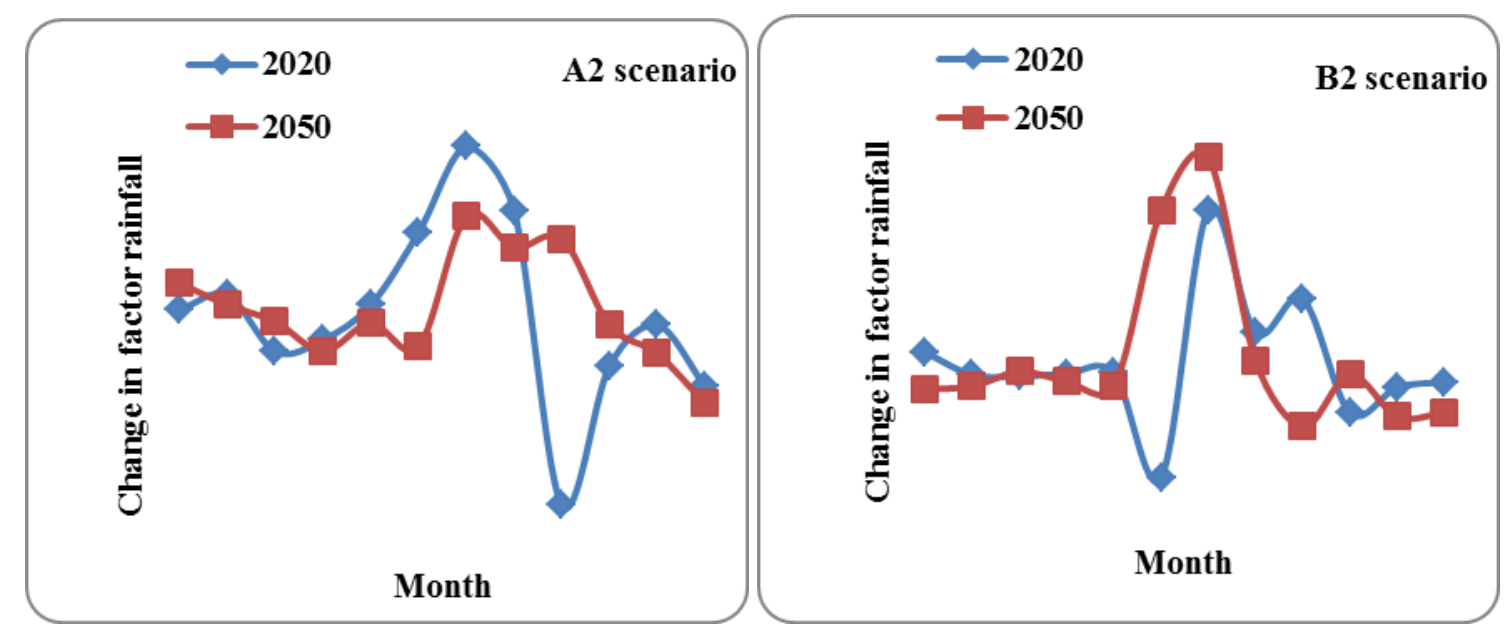

Figure.7 Change in grain yield (\%) under A2 and B2 scenarios

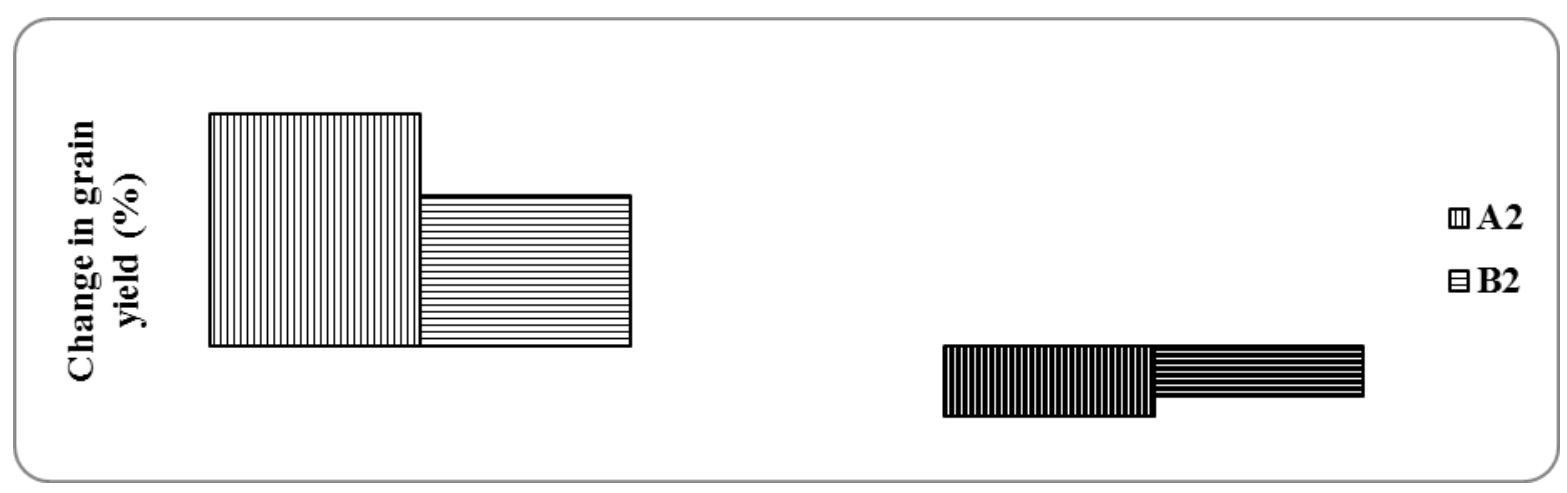

Figure.8 Change in anthesis and maturity appearance for the year 2020 and 2050 under A2 and B2 climate scenario

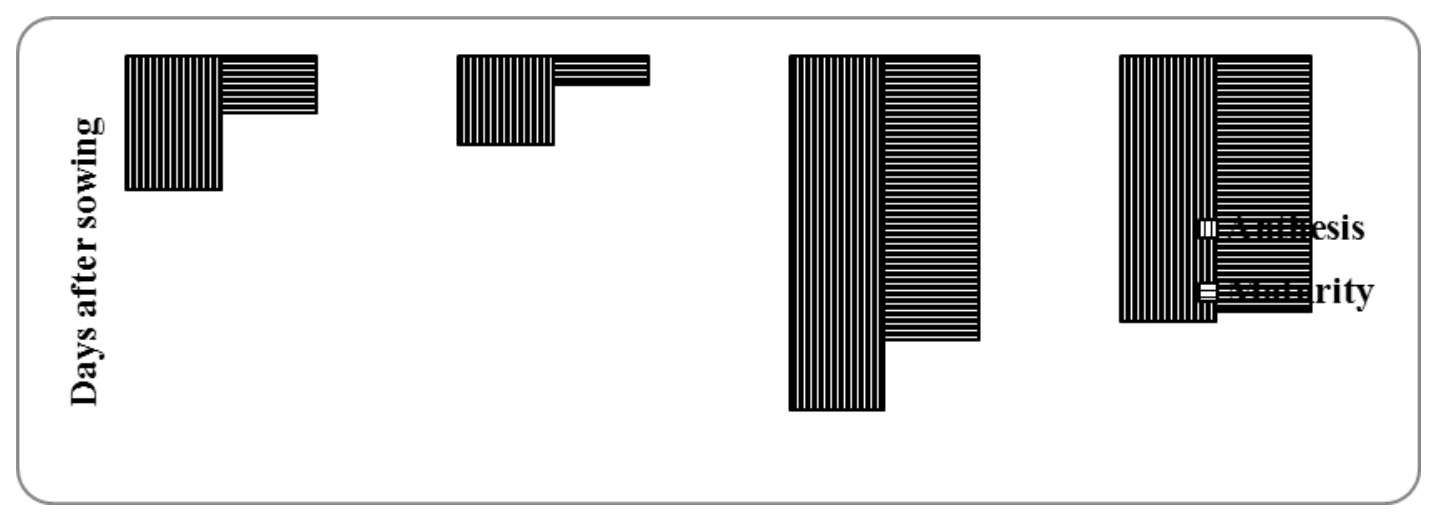


Figure.9 Change in grain yield (\%) under $\mathrm{CO}_{2}$ elevation of $200 \mathrm{ppm}$ and rise in temperature +2 ${ }^{\circ} \mathrm{C}$ above current value

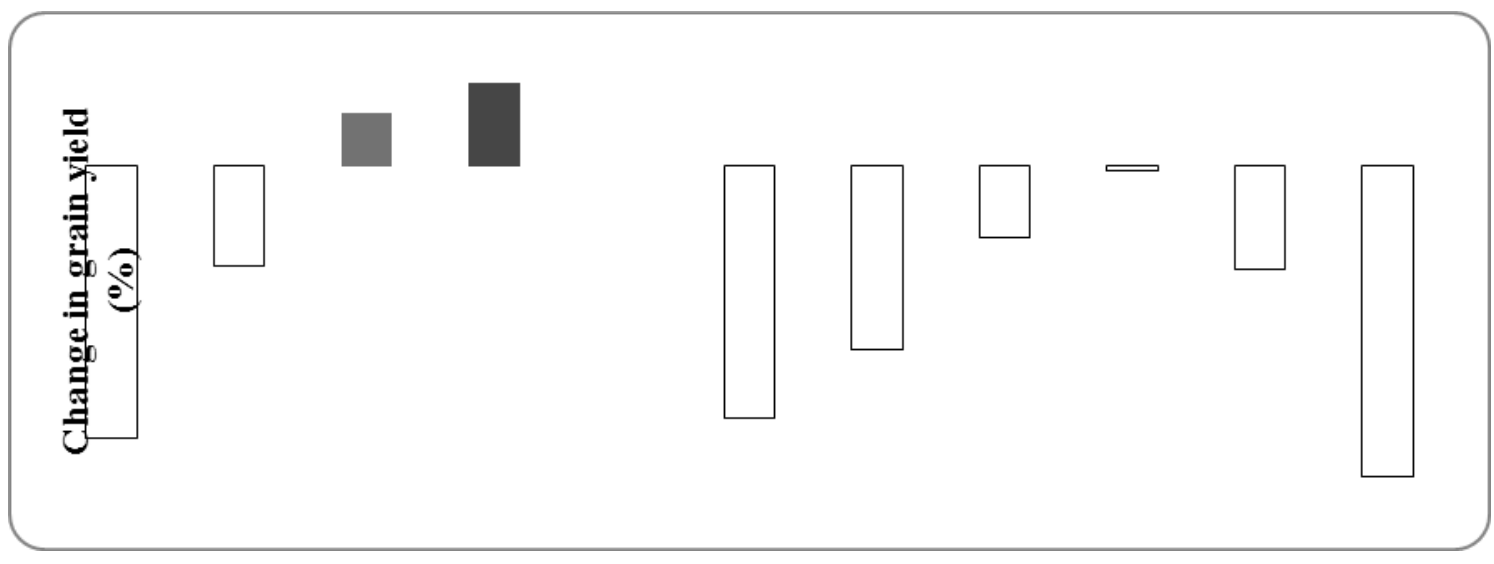

Figure.10 Anthesis and maturity days under $\mathrm{CO}_{2}$ elevation of $+200 \mathrm{ppm}$ and rise in temperature $+2{ }^{\circ} \mathrm{C}$ above current value for different sowing date

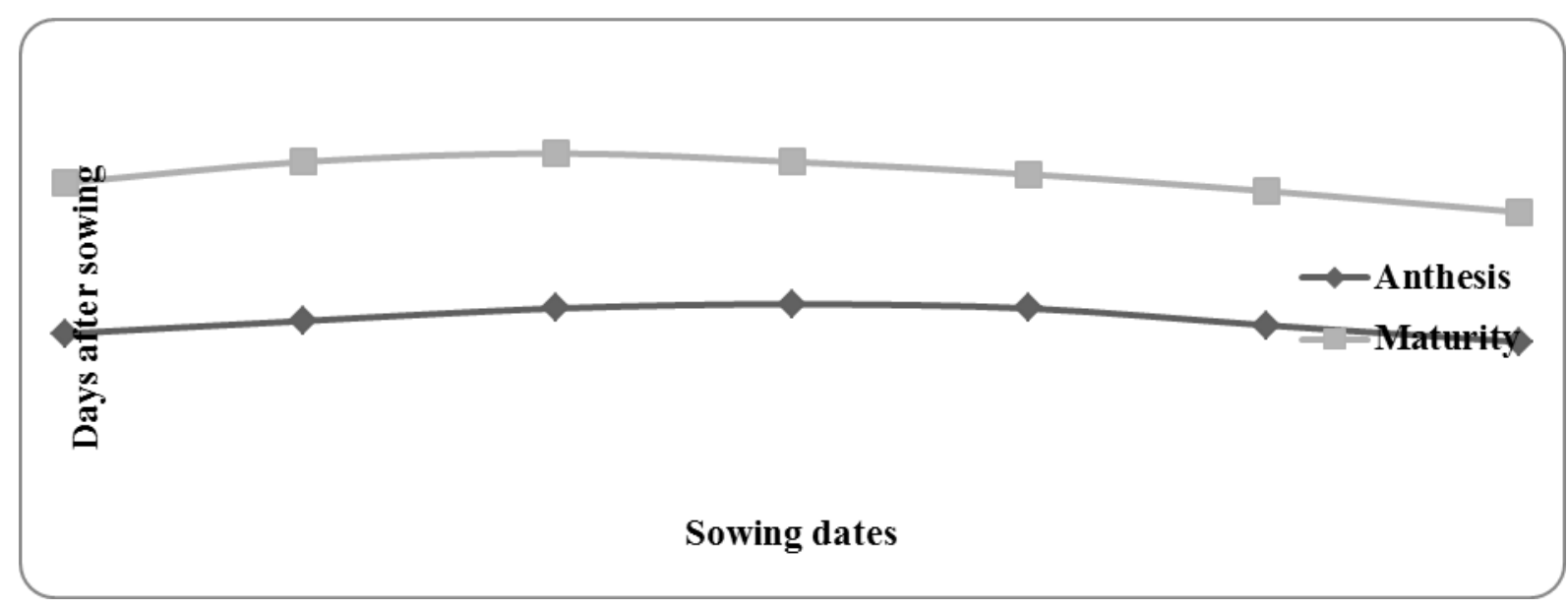

Figure.11 Change in grain yield (\%) under different sowing dates as compared to 30 November sowing and under different $\mathrm{N}$ fertilizer application rate as compared to $120 \mathrm{~kg} / \mathrm{ha}$ for the year 2050 under A2 scenario

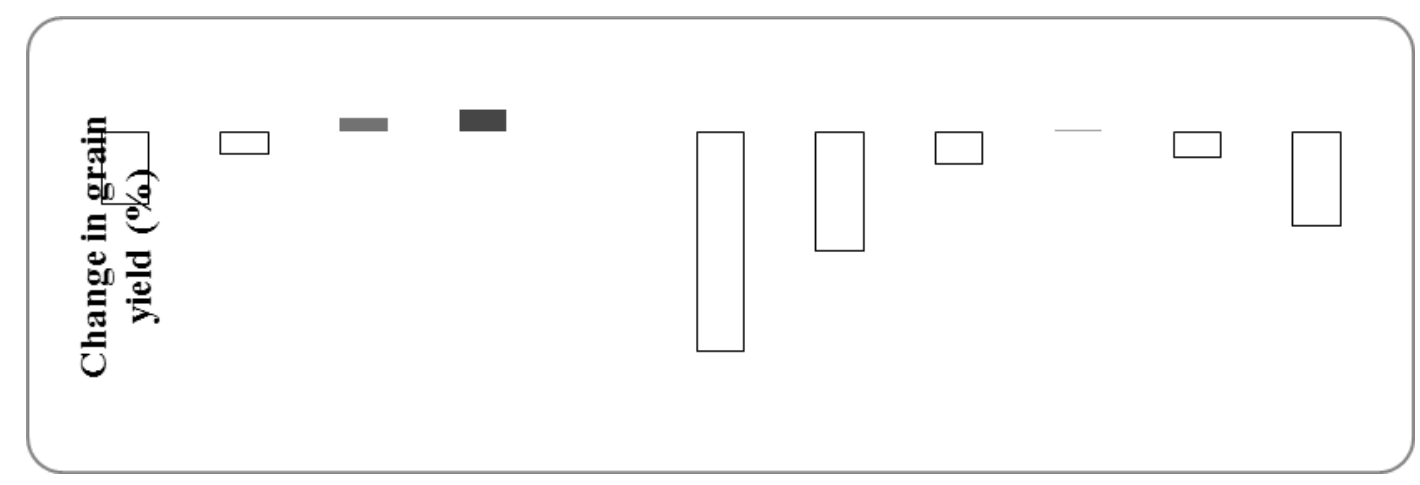


Figure.12 Effect of different sowing dates on appearance of anthesis and maturity in days after sowing of wheat crop for the year 2050 under A2 scenario

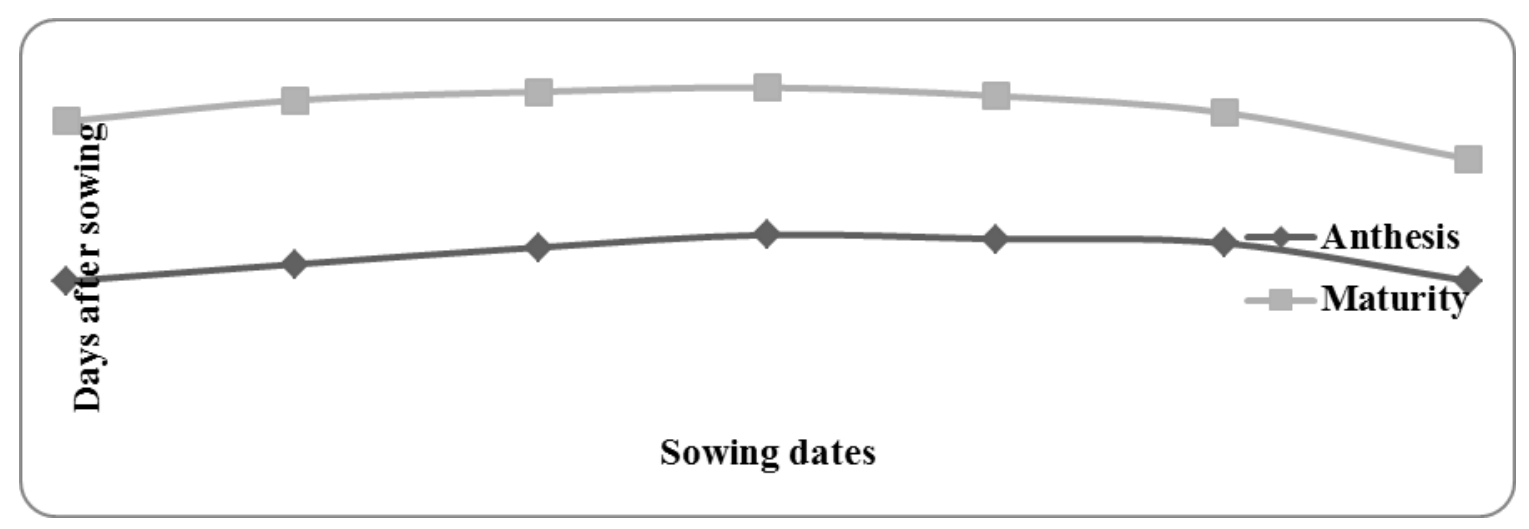

Figure.13 Change in grain yield (\%) under different sowing dates as compared to 30 November sowing and under different $\mathrm{N}$ fertilizer application rate as compared to $120 \mathrm{~kg} / \mathrm{ha}$ for the year 2050 under the B2 scenario

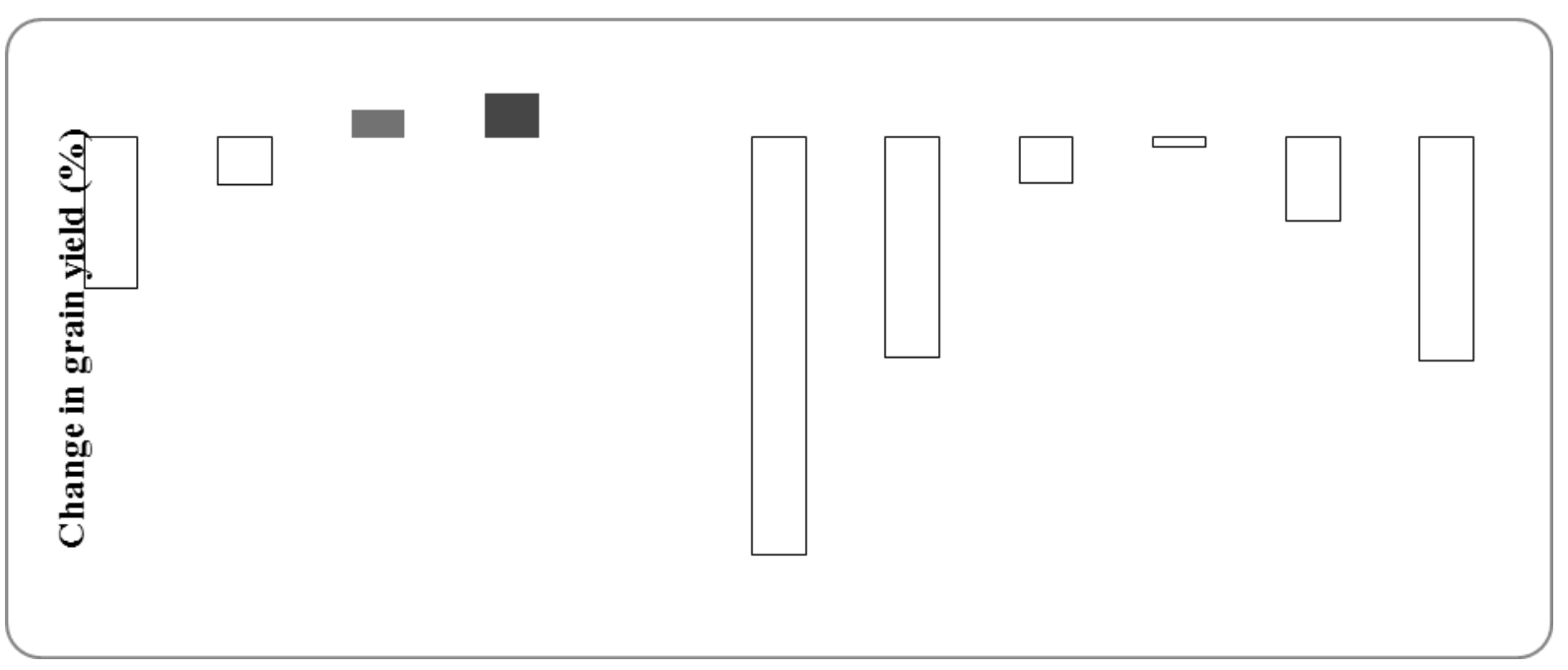

Figure.14 Effect of different sowing dates on appearance of anthesis and maturity in days after sowing of wheat crop for the year 2050 under B2 scenario

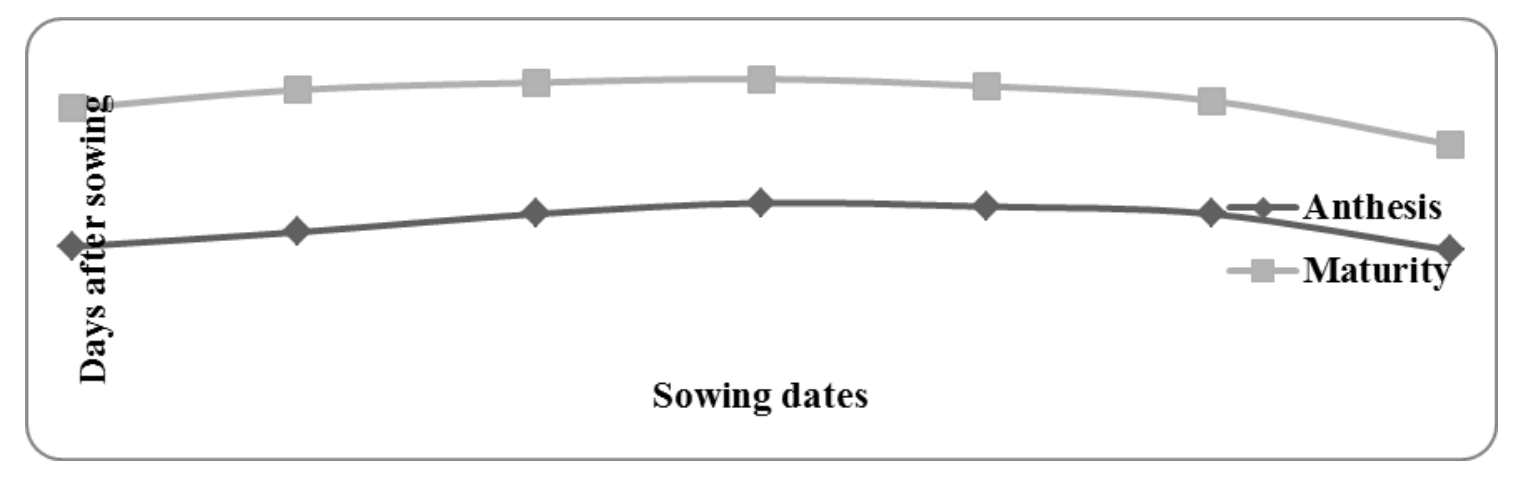


The summary and conclusions are as follows:

There was a good agreement between observed and simulated time series leaf area index, leaf weight, stem weight and tops weight of wheat crop with d-Stat value 0.87 , $0.89,0.98$ and 0.98 , respectively during calibration period (2010-2011). Similarly for validation period (2011-2012), the d-stat value between the observed and simulated time series leaf area index, leaf weight, stem weight and tops weight of wheat crop were $0.94,0.88,0.98$ and 0.92 , respectively. The variation between the observed and simulated value for grain yield was $6 \%$ and for tops weight was $14 \%$ during the validation period. The model was applied to simulate the grain yield of wheat crop, using the historical weather data. The simulated grain yield over past years was in decreasing trend with progress of year. The decrease in wheat yield over the past years could be due to increasing temperature over the years. The influence of different sowing dates and $\mathrm{N}$ fertilizer doses was simulated on change in yield of wheat crop. The minimum grain yield of $2729 \mathrm{~kg} / \mathrm{ha}$ was simulated on 15 October sowing and maximum grain yield of $3737 \mathrm{~kg} / \mathrm{ha}$ on 30 November sowing. Increase $\mathrm{N}$ fertilizer level up to 120 and $180 \mathrm{~kg} / \mathrm{ha}$ simulated the yield improvement 30 and $36 \%$ as compared to control (no N application). Further increasing $\mathrm{N}$ application did not simulate any significant yield improvement. Appearance of anthesis and maturity were 66 and 103 days after sowing for 30 November sowing date. Sowing earlier or later to 30 November reduced the maturity duration by 8-17 days. Increasing $\mathrm{CO}_{2}$ level of $100 \mathrm{ppm}$ and temperature $2{ }^{\circ} \mathrm{C}$ above the ambient simulated decline in grain yield $7 \%$. Alternate crop management practices including different sowing dates and rates of nitrogen fertilizers were investigated as adaptation measures to mitigate the effects of such climate change on grain yield, water use efficiency, anthesis and maturity days. To determine the optimum sowing dates, the potential outcomes of shifting the sowing dates 45 days before and 45 days after the current sowing date (30 November) with an interval of 15 days between successive sowing dates were investigated. Highest grain yield and water use efficiency were simulated under the normal sowing on 30 November. Differing sowing dates by 45 days from the normal (30 November) reduced the crop maturity duration by 5 days in early sowing, but 12 days in late sowing. With the developed A2 scenario, the grain yield increased by $0.6 \%$ by shifted the sowing date for 30 November to 15 December during the year 2050. However, in B2 scenario, the current sowing (30 November) continued to simulate the highest grain yield. In view of the research findings, the following conclusions are summarized. (a) The wheat sowing period around 30 November was simulated to be the best for increased production under the current and future climate scenario at Kharagpur, eastern India. (b)A marginal increase in yield was simulated by shifting the sowing time from 30 Nov to 15 December under future climate scenarios. (c) The $\mathrm{N}$ fertilizer application rate in the range 120 to $180 \mathrm{~kg} / \mathrm{ha}$ was recommended for the yield maximization.

\section{References}

Dettori, M., Cesaraccio C., Motroni A., Spano D. and Duce P. (2011). Using CERESWheat to simulate durum wheat production and phenology in Southern Sardinia, Italy. Field Crops Research, 120: 179-188.

Langensiepen, M., Hanus, H., Schoop, P. and Grasle, W. (2008). Validating CERES-wheat under North-German environmental conditions. Agricultural Systems, 97(1-2): 34-47.

Ma, H.L., Zhu, J.G., Liu, G., Xie, Z.B., Wang, Y.L., Yang, L.X. and Zeng, Q. 
(2007). Availability of soil nitrogen and phosphorus in a typical ricewheat rotation system under elevated atmospheric $\left[\mathrm{CO}_{2}\right]$. Field Crops Research, 100: 44-51.

Nagarajan, S., Jagadish, S., Hariprasad, A. K., Anand, A., Pal, M. and Agarwal, P. K. (2010). Local climate affects growth, yield and grain quality of aromatic and non-aromatic rice in northwestern India. Agriculture, Ecosystems and Environment, 138: 274-281.

Palosuo, T., Kersebaum, K. C., Angulo, C., Hlavinka, P., Moriondo, M., Olesen, J. E., Patil, R. H., Ruget, F., Rumbaur, C., Takac, J.,Trnka, M., Bindi, M., Caldag, B., Ewert, F., Ferrise, R., Mirschel, W., Saylan, L., Siska, B. and Rotter, R. (2011). Simulation of winter wheat yield and its variability in different climates of Europe: A comparison of eight crop growth models. European Journal of Agronomy, 35: 103-114.

Reidsma,P., Ewert, F., Lansink, A. and Leemans, R. (2010). Adaptation to climate change and climate variability in European agriculture: The importance of farm level responses. European Journal of Agronomy, 32: 91-102.

Singh, A. K., Tripathy, R. and Chopra, U. K. (2008). Evaluation of CERES-Wheat and CropSyst models for waternitrogen interactions in wheat crop. Agricultural Water Management, 96(7): 776-786.

Singh, U., Wilkens, P.W., Chude, V. and
Oikeh, S. (1999). Predicting the effect of nitrogen deficiency on crop growth duration and yield. In: Proceedings of the Fourth International Conference on Precision Agriculture, ASA-CSSASSSA, Madison, Wisconsin, USA, pp. 1379-1393.

Srivastava, A., Naresh, K. S. and Aggarwal, P.K. (2010). Assessment on vulnerability of sorghum to climate change in India. Agriculture, Ecosystems and Environment, 138: 160-169.

Timsina, J. and Humphreys, E. (2006). Performance of CERES-Rice and CERES-Wheat models in rice-wheat systems. Agricultural Systems, 90: 531.

Xiao, G., Zhang,Q., Li, Y., Wang, R., Yao, Y., Zhao, H. and Bai, H. (2010). Impact of temperature increase on the yield of winter wheat at low and high altitudes in semiarid northwestern China. Agricultural Water Management, 97: 1360-1364.

You, L., Rosegrant, M. W., Wood, S. and Sun, D. (2009). Impact of growing season temperature on wheat productivity in China. Agricultural and Forest Meteorology, 149: 10091014.

Ziska, L.H. (2008). Three-year field evaluation of early and late 20th century spring wheat cultivars to projected increases in atmospheric carbon dioxide. Field Crops Research, 108: 54-59.

\section{How to cite this article:}

Shatruhan Jaiswal Anuj Kumar and Uma Shanker Gupta. 2018. Simulation of Wheat Growth and Yield under Ambiance Change Impacts on Crop in Eastern India. Int.J.Curr.Microbiol.App.Sci. 7(07): 3488-3502. doi: https://doi.org/10.20546/ijcmas.2018.707.405 